\title{
The effect of irrigation method on the quality and shelf-life of strawberry fruit in organic production
}

\author{
Päivi Parikka \\ MTT Agrifood Research Finland, Plant Production Research, Plant Protection, Jokioinen, Finland \\ Paivi.parikka@mtt.fi
}

Organic production of strawberry was investigated at MTT Agrifood Research Finland during 2000-2002. Research topics included irrigation method and its effect on fruit quality. The experimental field at MTT Plant Protection in Jokioinen was equipped with drip irrigation and sprinkler irrigation systems.

Organically produced cultivars 'Jonsok' and 'Bounty' were planted in black plastic mulch in double rows, 20 plants per plot in four replicates. The area was fertilized before planting and no fertilizer was added during the production years. The field was divided into two areas: drip irrigation and no drip irrigation after start of flowering. Half of the area without drip irrigation was irrigated with sprinklers and the other half was left with natural rain only. Drip irrigation, and in 2002 sprinkler irrigation, was given according to tensiometer measurements. No fungicides or organic products were used to control grey mold and other diseases. One plot of both 'Jonsok' and 'Bounty' was covered with a small open plastic tunnel from the beginning of flowering to the end of harvest to investigate grey mold infection in a covered crop.

The fruit were harvested three times a week. To determine the shelf-life of the fruit, 40 berries of marketable quality were placed in plastic Jiffy pots on trays and covered with moist tissue paper. The trays were stored in room temperature $\left(+22-24^{\circ} \mathrm{C}\right)$ in black plastic bags. The berries were checked every day for grey mold and the infested ones were removed.

The fruit yield of 'Jonsok' was lower than that of 'Bounty' which was high especially in 2001, but in 2002 it suffered from a cool and rainy period during fruit ripening. Drip irrigation increased the yield of 'Jonsok' slightly as compared to the sprinkler-irrigated and non-irrigated plants. In 'Bounty', the increase was greater. The amount of grey mold in fruit was quite low in 2001 on both cultivars. Drip irrigation did not reduce grey mold in the harvested fruit in 2001 in 'Jonsok' and in 2002 it seemed to increase the amount of infested fruit as compared to sprinkler irrigation. 'Bounty' showed minor reduction of grey mould in 2001. The fruit from plots covered with plastic tunnels showed a very low grey mould infestation rate.

The shelf-life of strawberry fruit in room temperature was dependent on the weather conditions during harvest. During rainy periods more than $50 \%$ of the fruits were spoiled in two days, in 2002 in some pickings more than 30\% were discarded after one day. During dry periods the spoilage was delayed by a day or two. In general, 'Jonsok' had a shorted shelf-life than 'Bounty' and the shelf-life was longest for the fruit from plastic tunnels. If less than $40 \%$ of the fruit in these tests are discarded before the third day, the quality and storage properties in normal cool storage temperatures can be considered good. The irrigation method did not affect either the shelf-life or the quality of fruit.

In organic strawberry production grey mold is a major problem. Strawberry varieties differ from each other in disease susceptibility and the quality and shelf-life of the fruit is affected more by their properties and weather conditions than by the irrigation method. 